\title{
Cap-puncturing mechanism for ophthalmic postoperative antibiotic eye drops: friend or foe?
}

Chua Shee Wen ${ }^{1,2}$, Yong Meng Hsien ${ }^{1}$, Malisa Ami ${ }^{1}$, Rona Asnida Nasaruddin ${ }^{1}$, Mae-Lynn Catherine Bastion ${ }^{1}$, Jemaima Che Hamzah ${ }^{1}$

${ }^{1}$ Department of Ophthalmology, Universiti Kebangsaan Malaysia Medical Centre (UKMMC), Cheras, Wilayah Persekutuan Kuala Lumpur, Malaysia; '2Surgical Department, Faculty of Medicine and Health Science, Universiti Malaysia Sabah, Kota Kinabalu, Sabah, Malaysia

\section{Abstract}

A retrospective case series to highlight two cases of postoperative endophthalmitis, in which similar improper technique of puncturing the antibiotic bottle with a nonsterile needle was noted.

Patient A, a 65-year-old man with three weeks' history of uneventful combined cataract and pars plana vitrectomy (PPV) presented with acute painful right eye and vision blurring from $6 / 12$ to $1 / 60$ for two days. Examination showed severe anterior chamber activity and hazy fundal view. B-scan showed dense vitritis. Vitreous sampling revealed gram positive cocci, but no culture growth. Patient $B$, a 69-year-old man presented with three days' history of right painful red eye and vision dropped to light perception following an uneventful cataract surgery. Examination showed severe anterior chamber activity with hypopyon, raised intraocular pressure, and no fundal view. B-scan detected dense vitritis with loculation. Vitreous sampling cultured Pseudomonas aeruginosa in Patient B. In both cases, the patients reported piercing the generic topical ciprofloxacin $0.3 \%$ bottle tip with a nonsterile needle instead of the prescribed method of using the sterile, inner aspect of the bottle cap. However, the cultures of the bottle contents were negative in both cases. Both patients received intravitreal, topical, and systemic antibiotics and subsequently underwent PPV. Patient A recovered vision

Correspondence: Dr. Malisa Ami, Department of Ophthalmology, Universiti Kebangsaan Malaysia Medical Centre, Jalan Yaacob Latif, Bandar Tun Razak, 56000, Cheras, Wilayah Persekutuan Kuala Lumpur.

E-mail:misha_ami@yahoo.co.uk 
to baseline, while Patient $B$ recovered to counting finger vision.

In conclusion, the cap-puncturing mechanism for eye drop bottles is designed to maintain the sterility of the contents. However, this may backfire when patients do not understand the prescribed technique. We postulate that this improper technique predisposed the two cases to endophthalmitis. Measures to overcome this include a detailed explanation alongside a demonstration or immediate instillation from a new bottle opened in theatre, which the patient then takes home after the surgery.

Keywords: cap puncture with needle, contaminated eyedrops, postoperative care, postoperative infective endophthalmitis

\section{Mekanisme teknik tusukan hujung ubat titis antibiotik mata untuk pesakit selepas pembedahan; selamat atau tidak?}

\section{Abstrak}

Siri kes retrospektif untuk menyerlahkan dua kes endoftalmitis selepas pembedahan mata, di mana teknik tusukan muncung botol antibiotik yang tidak sepatutnya digunakan iaitu dengan menggunakan jarum tidak steril.

Pesakit A, seorang lelaki berusia 65 tahun yang telah menjalani pembedahan gabungan katarak dan vitrektomi pars plana (TPPV) tiga minggu sebelumnya datang dengan gejala sakit berserta penglihatan kabur akut dari 6/12 menjadi 1/60 dalam masa dua hari. Pemeriksaan menunjukkan keradangan ruang anterior yang teruk dan pandangan fundus yang sangat kabur. B-scan menunjukkan vitritis padat. Sampel vitreous mendedahkan cocci gram positif, tetapi tiada pertumbuhan pada media kultur. Pesakit B, seorang lelaki berusia 69 tahun yang telah mejalani pembedahan katarak yang lancar sebelumnya mengalami gejala mata merah dan kabur penglihatan yang drastik iaitu hanya melihat cahaya (PL). Pemeriksaan menunjukkan radang aktiviti ruang anterior sangat teruk dengan hypopyon, peningkatan tekanan intraokular, dan tidak ada penglihatan untuk fundus.Bscan mengesan vitritis padat berserta lokulasi. Pseudomonas aeruginosa ditemui dalam Pesakit B. Dalam kedua-dua kes, pesakit melaporkan menusuk hujung muncung botol ciprofloxacin topikal generik $0.3 \%$ dengan jarum tidak steril dan bukannya dengan kaedah yang ditetapkan menggunakan teknik steril iaitu sepatutnya menggunakan hujung khas yang disediakan pada penutup botol. Walau bagaimanapun, kultur pertumbuhan organisma kandungan botol adalah negatif dalam kedua-dua kes. Kedua-dua pesakit menerima antibiotik intravitreal, topikal, 
dan sistemik dan seterusnya menjalani PPV. Pesakit A penglihatan yang pulih ke tahap sebelumnya, manakala Pesakit B hanya pulih sedikit ke tahap penglihatan kiraan jari.

Sebagai kesimpulan, mekanisme tusukan pada muncung botol titis mata direka untuk mengekalkan tahap steril kandungan. Walau bagaimanapun, ini mungkin menjadi satu masalah apabila pesakit tidak memahami teknik yang ditetapkan. Kami berpendapat bahawa teknik yang tidak betul ini telah menyumbang kepada dua kes endophthalmitis ini. Langkah-langkah untuk mengatasi masalah ini termasuk penjelasan terperinci bersama demonstrasi atau instilasi segera dari botol baru yang dibuka di teater, yang kemudiannya dibawa pulang selepas pembedahan.

Kata kunci: endoftalmitis, jangkitan kuman pasca-pembedahan, penjagaan pascapembedahan, tusukan penutup botol dengan jarum, ubas titis yang tercemar

\section{Introduction}

Postoperative infective endophthalmitis is a potentially vision-threatening complication and is the most devastating ocular infection. Prophylactic usage of topical antibiotic is aimed at preventing this feared complication of ophthalmic surgery. ${ }^{1}$

Some eye drop bottles are manufactured with a cap-puncturing mechanism to maintain the sterility of the bottle before the first instillation. ${ }^{2}$ Piercing the bottle tip with a nonsterile instrument not fit for purpose may lead to contamination of the bottle.

\section{Purpose}

The purpose is to highlight two cases of postoperative infective endophthalmitis, in which a similar improper technique of puncturing the antibiotic bottle with a nonsterile needle was noted.

\section{Methods}

Retrospective case series.

\section{Cases}

Patient A, a 65-year-old man with underlying hypertension, dyslipidaemia, and ischaemic heart disease with no known diabetes, presented to eye clinic three weeks 


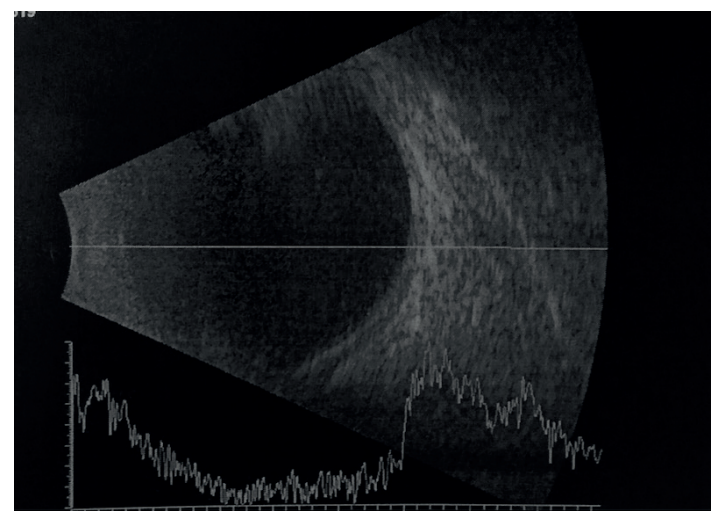

Fig. 1. B-scan of Patient A showed dense vitritis.

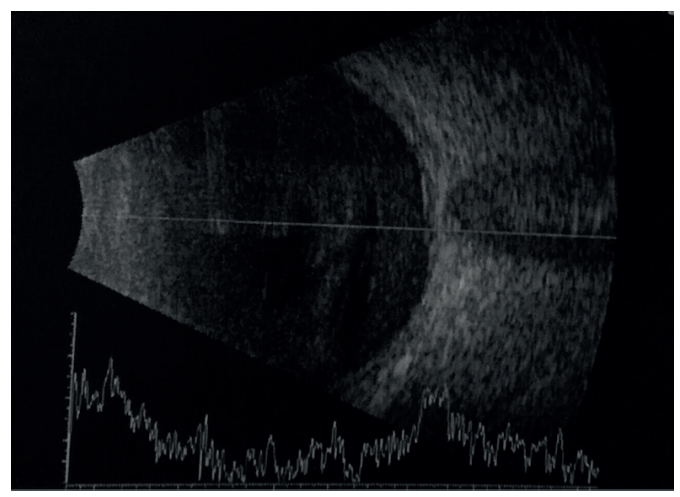

Fig. 2. B-scan of Patient B showed dense vitreous opacities with loculations.

after an uneventful combined cataract and pars plana vitrectomy (PPV) for epiretinal membrane removal for his right eye. The patient had been using topical dexamethasone $0.1 \%$ every 2 hours and generic topical ciprofloxacin $0.3 \%$ every 2 hours postoperatively in the right eye. Preoperative best corrected visual acuity (BCVA) was $6 / 24$, which improved to $6 / 12$ post-operatively. He presented with acute pain, redness, and poor vision for two days in the right eye, recorded at $1 / 60$. Ophthalmic examination revealed a reactive pupil without relative afferent pupillary defect (RAPD), injected conjunctiva, and severe anterior chamber activity, but absence of hypopyon. Posterior segment view was hazy and there was dense vitritis, but no obvious loculation on B-scan (Fig. 1). Acute postoperative infective endophthalmitis was diagnosed and treatment with intravitreal injection of vancomycin $2 \mathrm{mg} / 0.1 \mathrm{ml}$ and ceftazidime $2 \mathrm{mg} / 0.1 \mathrm{ml}$ was administered immediately after vitreous sampling. The patient also received intensive instillation of topical antibiotics (gentamicin $0.9 \%$ and ceftazidime $5 \%$ ) and oral ciprofloxacin $750 \mathrm{mg}$ twice daily. Vitreous 
a

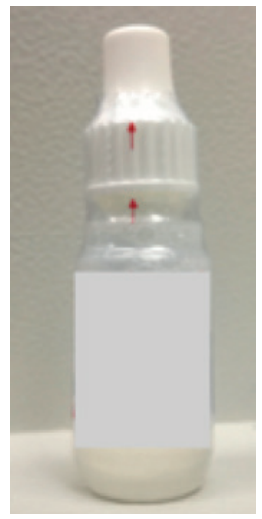

$\mathrm{b}$

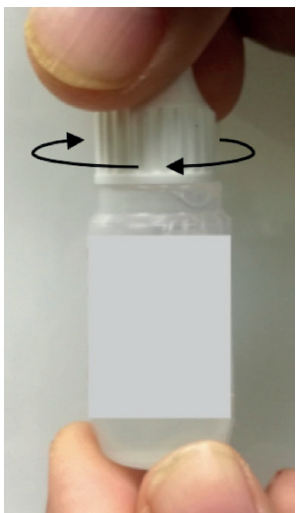

Fig. 3. (a) Unopened, new bottle with the cap positioned at a specific distance from the nozzle. (b) Method of tightening the cap on the nozzle to pierce the bottle tip before instillation of the eye drops.

sampling revealed gram positive cocci, but there was no culture growth. There was no improvement after 48 hours and the patient subsequently underwent PPV with repeated intravitreal antibiotics injection. Postsurgery, the condition improved, and he recovered to baseline BCVA.

Patient B, a 69-year-old man with underlying hypertension, presented three days after an uneventful right cataract surgery with a painful, red eye and only light perception vision in his right eye. The patient had been using topical dexamethasone $0.1 \%$ every 2 hours and generic topical ciprofloxacin $0.3 \%$ every 2 hours post-operatively on the right eye. Pupil light reaction was brisk without a RAPD. There was conjunctival and scleral injection with oedematous cornea. The anterior chamber showed severe inflammation with hypopyon, and intraocular pressure was elevated at $35 \mathrm{mmHg}$. Posterior segment examination revealed no fundal view and B-scan revealed dense vitreous opacities with loculations (Fig. 2). The patient was treated as acute postoperative infective endophthalmitis with standard management, similar to Patient $A$. He received intravitreal vancomycin $2 \mathrm{mg} / 0.1 \mathrm{ml}$ and ceftazidime $2 \mathrm{mg} / 0.1 \mathrm{ml}$ immediately after vitreous sampling, intensive topical gentamicin $0.9 \%$ and ceftazidime $5 \%$, and oral ciprofloxacin $750 \mathrm{mg}$ twice daily. Pseudomonas aeruginosa was isolated from the vitreous culture and the patient subsequently underwent PPV. The intraocular inflammation resolved postvitrectomy, but visual recovery was limited to counting fingers.

In both cases, the patients reported piercing the generic topical ciprofloxacin $0.3 \%$ bottle tip with a nonsterile needle because they were otherwise unable to get the eye drops out of the bottle. This was despite the bottles having been dispensed with written instructions on how to puncture the bottle with the inner aspect of the cap. Both cases occurred just two months apart.

On both occasions, the cases were subsequently reported to the National Eye 
Database endophthalmitis notification system, hospital operative theatre administration team, and adverse drug reaction notification system. Investigations were carried out, including culture of the contents of the postoperative eye drops. There was no evidence of cluster endophthalmitis, nor contamination of the batch of eye drops or operation theatre. The occurrence of this rare complication of ocular surgery also prompted a review of patient counselling by the Pharmacy department staff dispensing the medication.

\section{Discussion}

There are a number of limitations in our report. First, the two cases did not undergo the same procedure, as one case was as cataract surgery and the other was a combination of cataract and vitrectomy surgery. Cataract and vitrectomy surgery have different risks for endophthalmitis. However, in both cases the cataract surgery resulted in a corneal wound. This meant that Patient $A$ had an increased risk for endophthalmitis, similar to Patient $B$, compared to a patient undergoing routine PPV alone.

Secondly, vitreous taps suggested different organisms in each case, but bottle cultures were negative in both. A similar organism to the tap could not be demonstrated in either case, which would have strongly suggested a link with the incorrect cap puncturing technique. However, they each received the same perioperative antibiotic and admitted to using non-sterile objects to puncture the bottle caps. We postulate that the antibiotic bottles were contaminated by the nonsterile needle, particularly the bottle tips. The bottle tips were not tested separately in these cases and might have been able to yield the organism.

The aim of perioperative antibiotic prophylaxis is to lower the risk of endophthalmitis after surgery. ${ }^{1}$ However, instillation of contaminated eye drops in postoperative cases may lead to adverse effects. The cap-puncturing mechanism for eye drop bottles is designed with an in-built self-piercing mechanism incorporated to ensure sterility of the bottle content up until the first instillation. Before opening the bottle for the first time, the user is required to tighten the cap on the nozzle by turning it clockwise to allow the spike located on the underside of the cap to pierce the tip of the bottle (Fig. 3a and 3b). ${ }^{2}$ However, this may backfire when patients do not understand this mechanism despite written instructions and explanatory diagrams, resulting in inadvertent potential contamination of contents ${ }^{3}$ due to puncturing of the bottle tip in a non-sterile manner. We are postulating that this improper and risky cap-puncturing technique may have subsequently led to a very rare infection, namely endophthalmitis, as illustrated in these two cases. The only common risk factor found in these two patients was this incorrect technique. Previous studies have found that bottle tips are more often contaminated than the bottle content, ${ }^{4}$ which may explain the negative culture of the bottle contents in these two cases 
when the whole bottles were sent for the tests. A number of articles on postoperative endophthalmitis secondary to various types of contaminated eye drops or solutions have been described previously, ${ }^{5,6}$ but none were related to the cap-puncturing mechanism as in these cases.

Our aim in reporting the two cases is to highlight that the cap-puncturing mechanism for eye drops may be used incorrectly by patients, resulting in increased risk for potentially serious and blinding postoperative infections. To mitigate this risk, we would like to suggest implementing measures to overcome this bottle-related contamination, which includes a detailed explanation alongside a demonstration of the proper cap-puncturing technique or instillation from the new bottle by medical staff immediately after operation, which the patient then takes home after surgery. This will help to avoid misunderstandings and improper cap-puncturing technique due to the patient's inability to understand even written instructions. Prevention is definitely better than cure, as both patients eventually required another operation, namely PPV, and Patient B went on to have a poor visual outcome.

\section{Conclusion}

An incorrect cap-puncturing method of the postoperative antibiotic bottle was the common risk factor found in two patients with postoperative endophthalmitis, which may have predisposed them to this sight-threatening postoperative complication.

\section{References}

1. Gower EW, Lindsley K, Tulenko SE et al. Perioperative antibiotics for prevention of acute endophthalmitis after cataract surgery. Cochrane Database Syst Rev. 2017;2:CD006364.

2. Drug label information of cap puncturing eyedrops (example). Available from: https://dailymed.nlm. nih.gov/dailymed/fda/fdaDrugXsl.cfm?setid=45ff37cf-bb29-4e8b-99b4-881967ef61b3\&type=display.

3. An JA, Kasner O, Samek DA, et al. Evaluation of eyedrop administration by inexperienced patients after cataract surgery. J Cataract Refract Surg. 2014;40(11):1857-1861.

4. Nentwich MM, Kollmann KHM, Meshack J et al. Microbial contamination of multi-use ophthalmic solutions in Kenya. Br J Ophthalmol. 2007;91(10):1265-1268.

5. Lalitha P, Das M, Purva PS et al. Postoperative endophthalmitis due to Burkholderia cepacia complex from contaminated anaesthetic eye drops. Br J Ophthalmol. 2014;98(11):1498-1502.

6. Swaddiwudhipong W, Tangkitchot T, Silarug N. Morbidity and Mortality Weekly Report. 1996;45(23);491-494. 